September 2006

\title{
The "Odious Scourge": Evolving Interpretations of the Crime of Genocide
}

William A. Schabas

Follow this and additional works at: https://digitalcommons.usf.edu/gsp

\section{Recommended Citation}

Schabas, William A. (2006) "The "Odious Scourge": Evolving Interpretations of the Crime of Genocide," Genocide Studies and Prevention: An International Journal: Vol. 1: Iss. 2: Article 3.

Available at: https://digitalcommons.usf.edu/gsp/vol1/iss2/3

This Articles is brought to you for free and open access by the Open Access Journals at Digital Commons @ University of South Florida. It has been accepted for inclusion in Genocide Studies and Prevention: An International Journal by an authorized editor of Digital Commons @ University of South Florida. For more information, please contact digitalcommons@usf.edu. 


\title{
The "Odious Scourge"': Evolving Interpretations of the Crime of Genocide
}

\author{
William A. Schabas \\ National University of Ireland, Galway, \\ and Irish Centre for Human Rights
}

The crime of genocide was defined in the 1948 Convention on the Prevention and
Punishment of the Crime of Genocide in reaction to the concept of crimes against
humanity developed at Nuremberg, which insisted upon a connection with
aggressive war in prosecutions for atrocity crimes. The convention stated genocide
could be committed in time of peace, but it also narrowed the scope of the crime
itself to the intentional destruction of a national, ethnic, racial, or religious group.
Cultural genocide was intentionally excluded. Although the text of the definition
remains unchanged, judicial interpretation has broadened it significantly. Recent
decisions have held that there is no requirement of a state plan or policy. They have
also set out a subjective approach to identification of the protected group. Although
cultural genocide in an extensive sense is still not recognized within the definition,
there is a definite tendency to extend the concept to what is colloquially called
"ethnic cleansing." These broadening definitions influence determinations about
genocides, even those committed many years ago.

When hundreds of thousands of Armenians living within the Ottoman Empire perished in $1915,{ }^{1}$ the governments of France, Great Britain, and Russia responded with an unprecedented declaration. Dated 24 May 1915, it asserts that "in the presence of these new crimes of Turkey against humanity and civilization, the allied Governments publicly inform the Sublime Porte that they will hold personally responsible for the said crimes all members of the Ottoman Government as well as those of its agents who are found to be involved in such massacres." ${ }^{2}$ It has been suggested that this constitutes the first use, at least within an international law context, of the term "crimes against humanity." 3

According to the Treaty of Sèvres, signed on 10 August 1920, Turkey recognized the right of trial "notwithstanding any proceedings or prosecution before a tribunal in Turkey" and was obliged to surrender "all persons accused of having committed an act in violation of the laws and customs of war, who are specified either by name or by rank, office or employment which they held under Turkish authorities."4 This formulation is similar to the war crimes clauses in the Treaty of Versailles. ${ }^{5}$ But the Treaty of Sèvres contains a major innovation, contemplating prosecution for the massacres committed within Turkey by the Turkish regime, as well as of war crimes committed against Allied soldiers or civilians within occupied territories. Pursuant to article 230,

The Turkish Government undertakes to hand over to the Allied Powers the persons whose surrender may be required by the latter as being responsible for the massacres committed during the continuance of the state of war on territory which formed part of the Turkish Empire on the 1st August, 1914. The Allied Powers reserve to themselves 
the right to designate the Tribunal which shall try the persons so accused, and the Turkish Government undertakes to recognise such Tribunal. In the event of the League of Nations having created in sufficient time a Tribunal competent to deal with the said massacres, the Allied Powers reserve to themselves the right to bring the accused persons mentioned above before the Tribunal, and the Turkish Government undertakes equally to recognise such Tribunal. ${ }^{6}$

Though signed by all the parties, including Turkey, the Treaty of Sèvres was never ratified and never, therefore, came into force. As Kay Holloway writes, the failure of the signatories to bring the treaty into effect "resulted in the abandonment of thousands of defenceless peoples-Armenians and Greeks-to the fury of their persecutors, by engendering subsequent holocausts in which the few survivors of the 1915 Armenian massacres perished." The Treaty of Sèvres was replaced on 24 July 1923 by the Treaty of Lausanne, ${ }^{8}$ an instrument that contains a "Declaration of Amnesty" for all offences committed between 1 August 1914 and 20 November 1922.

When the Armenian massacres took place, the term "genocide" did not yet exist. It was not devised until three decades later, in 1944, by a Polish-Jewish law professor, Raphael Lemkin, by then living in exile in the United States, in his book Axis Rule in Occupied Europe. ${ }^{9}$ Rarely has a neologism had such rapid success. ${ }^{10}$ Within little more than a year of its introduction into the English language, ${ }^{11}$ the word "genocide" was being used in the indictment of the International Military Tribunal, and within two, it was the subject of a UN General Assembly resolution. ${ }^{12}$ But the resolution spoke in the past tense, describing genocide as crimes that "have occurred." By the time the General Assembly had completed its initial standard setting in this area, with the 1948 adoption of the Convention on the Prevention and Punishment of the Crime of Genocide (UNCG), "genocide" had a detailed and quite technical definition as a crime against the law of nations. The preamble of that instrument recognizes "that at all periods of history genocide has inflicted great losses on humanity." Genocide is described as "the odious scourge."

\section{"Crimes against Humanity" or "Genocide"}

When the term "crimes against humanity" was initially used by the Allies in 1915 to describe the Armenian massacres, it had no recognized definition. In 1945, the London Conference, composed of the four victorious powers (the United States, France, the United Kingdom, and the Soviet Union), codified the term as a basis for the prosecution of Nazi criminals. They defined it as follows:

CRIMES AGAINST HUMANITY: namely, murder, extermination, enslavement, deportation, and other inhumane acts committed against any civilian population, before or during the war, or persecutions on political, racial or religious grounds in execution of or in connection with any crime within the jurisdiction of the Tribunal, whether or not in violation of the domestic law of the court where perpetrated. ${ }^{14}$

The term was meant to cover atrocities committed within Germany against Germans, as distinction from war crimes, which were committed against non-German combatants or against civilians in occupied territories. The concept of "war crimes" had long been recognized as customary international law and was codified in the regulations annexed to the fourth Hague Convention of $1907 .{ }^{15}$ It was more than adequate to deal with the atrocities committed by the Nazis in occupied territories. But the idea that a government and its own officials could be held responsible for atrocities committed within their own borders against their own nationals was a bold leap forward in international law. This helps us to understand the guarded remarks of US 
Secretary of State Robert Lansing, who, in 1915, admitted what he called the "more or less justifiable" right of the Turkish government to deport the Armenians to the extent that they lived "within the zone of military operations." But, he said,

it was not to my mind the deportation which was objectionable but the horrible brutality which attended its execution. It is one of the blackest pages in the history of this war, and I think we were fully justified in intervening as we did on behalf of the wretched people, even though they were Turkish subjects. ${ }^{16}$

In 1945, although the victorious great powers accepted that the post-war prosecutions should include crimes committed within Germany against German civilians, they were nervous about the extent of the concept of "crimes against humanity," because, in recognizing that application of international law to atrocities committed against a state's own civilian population, they left themselves vulnerable to eventual prosecution as well. At the time, lynching of African-Americans was relatively widespread within the United States, and several American jurisdictions imposed a form of apartheid whose features are well known. The British and the French, with their colonial territories in Africa and Asia, and the Soviets, who had just deported millions from Chechnya and Ingushetia, were similarly exposed. For this reason, the four parties at the London Conference imposed what has come to be known as the "nexus," namely, a requirement that crimes against humanity be committed "in connection with any crime within the jurisdiction of the Tribunal." Consequently, crimes against humanity, as defined at Nuremberg, could be committed only within the context of war crimes or crimes against peace. They could not, pursuant to the definition, be committed in peacetime. ${ }^{17}$

Robert Jackson, the head of the US delegation at the London Conference, speaking of the proposed crime of "atrocities, persecutions, and deportations on political, racial or religious grounds" (this was how the concept of "crimes against humanity" was first identified in the debates), revealed the lingering concerns of his government:

\begin{abstract}
Ordinarily we do not consider that the acts of a government toward its own citizens warrant our interference. We have some regrettable circumstances at times in our own country in which minorities are unfairly treated. We think it is justifiable that we interfere or attempt to bring retribution to individuals or to states only because the concentration camps and the deportations were in pursuance of a common plan or enterprise of making an unjust or illegal war in which we became involved. We see no other basis on which we are justified in reaching the atrocities which were committed inside Germany, under German law, or even in violation of German law, by authorities of the German state. ${ }^{18}$
\end{abstract}

The International Military Tribunal, sitting at Nuremberg in 1945 and 1946, confirmed the limited scope of crimes against humanity in its final judgment. Although there was frequent reference to the preparations for the war and to the Nazi atrocities committed in the early years of the Third Reich, no conviction was registered for any act committed prior to 1 September $1939 .{ }^{19}$ Despite what has sometimes been suggested as an ambiguity in the Nuremberg Charter, the judges of the International Military Tribunal were faithful to the intent of the drafters. They entrenched the nexus between crimes against humanity and aggressive war.

\title{
Defining Genocide
}

Dissatisfaction and frustration with this limited concept of "crimes against humanity" emerged in the final months of 1946, within days of the judgment at Nuremberg. The initiatives came from states in what would later be called the Third World, 
specifically India, Cuba, Panama, and Saudi Arabia. Unlike the great powers, who feared that a broad scope for the term "crimes against humanity" might ultimately rebound to challenge repressive acts committed by them within their far-flung empires, the vulnerable emerging states of the underdeveloped world contemplated an instrument that would protect them. For the latter, it was a priority to recognize international criminalization of atrocities in peacetime, that is, applicable during the banal everyday reality of colonial and postcolonial societies. They sought and obtained this recognition, but only for a more narrowly described form of crime against humanity: genocide. Article II of the 1948 UNCG defines genocide as follows:

In the present Convention, genocide means any of the following acts committed with intent to destroy, in whole or in part, a national, ethnical, racial or religious group, as such:

(a) Killing members of the group;

(b) Causing serious bodily or mental harm to members of the group;

(c) Deliberately inflicting on the group conditions of life calculated to bring about its physical destruction in whole or in part;

(d) Imposing measures intended to prevent births within the group;

(e) Forcibly transferring children of the group to another group.

This was not the first attempt to define the term. In 1944, Lemkin had proposed the following definition:

a co-ordinated plan of different actions aiming at the destruction of essential foundations of the life of national groups, with the aim of annihilating the groups themselves. The objective of such a plan would be disintegration of the political and social institutions of culture, language, national feelings, religion, and the economic existence of national groups and the destruction of the personal security, liberty, health, dignity and even the lives of the individuals belonging to such groups. Genocide is directed against the national group as an entity, and the actions involved are directed against individuals, not in their individual capacity, but as members of the national group. $^{20}$

In a sense, Lemkin's definition is narrow, in that it addresses crimes directed against "national groups" rather than against "groups" in general. At the same time, it is broad, to the extent that it contemplates not only physical genocide but also acts aimed at destroying the culture and livelihood of the group.

When Cuba, India, and Panama proposed that the question of genocide be put on the agenda of the first session of the UN General Assembly, in late 1946, ${ }^{21}$ they did not have a full-blown definition to suggest. Their draft resolution states that "genocide is a denial of the right to existence of entire human groups in the same way as homicide is the denial of the right to live for individual human beings." 22 The result of this initiative, Resolution 96(I), adopted on 11 December 1946, went somewhat further in defining the crime:

Genocide is a denial of the right of existence of entire human groups, as homicide is the denial of the right to live of individual human beings; such denial of the right of existence shocks the conscience of mankind, results in great losses to humanity in the form of cultural and other contributions represented by these human groups, and is contrary to moral law and to the spirit and aims of the United Nations. Many instances of such crimes of genocide have occurred when racial, religious, political and other groups have been destroyed, entirely or in part... ${ }^{23}$ 
These efforts at definition were taken into account during the subsequent work of drafting the UNCG, but none was adopted. Lemkin's emphasis on what would be called "cultural genocide," that is, the destruction of the group's institutions rather than of its physical existence, was bluntly dismissed, ${ }^{24}$ although a shadow of the idea reappeared in the final version, which lists the forcible transfer of children from one group to the other as a punishable act. ${ }^{25}$ As for the 1946 resolution of the General Assembly, its inclusion of political groups was not reaffirmed. The result, in Article II of the 1948 convention, is a definition that is exceedingly narrow. Arguably, it covers only physical (and biological) destruction, with the minor exception of transferring children. Moreover, the enumeration of targeted groups is limited to four cognate concepts: race, religion, ethnicity, and nationality. For example, political and "other" groups are excluded, a tragic "blind spot" according to some critics. ${ }^{26}$ Other commentators have proposed new definitions in order to enlarge the scope of the term, especially the list of protected groups; among them are Stefan Glaser, ${ }^{27}$ Israel W. Charny, ${ }^{28}$ Vahakn Dadrian, ${ }^{29}$ Helen Fein, ${ }^{30}$ and Frank Chalk and Kurt Jonassohn. ${ }^{31}$ The most extreme position applies the term "genocide" to any and all groups. According to Pieter Drost, one of the early advocates of this view, "a convention on genocide cannot effectively contribute to the protection of certain described minorities when it is limited to particular defined groups... It serves no purpose to restrict international legal protection to some groups; firstly, because the protected members always belong at the same time to other unprotected groups." 32

This is not, however, the course that international law has followed. The 1948 definition has stood the test of time. Recently, it was included without significant change in such instruments as the statutes of the ad hoc criminal tribunals for the former Yugoslavia and Rwanda, ${ }^{33}$ the International Law Commission's Code of Crimes against the Peace and Security of Mankind, ${ }^{34}$ and the Rome Statute of the International Criminal Court. ${ }^{35}$ Implementing legislation of the Rome Statute adopted in many countries has confirmed the dominance of the 1948 definition in national criminal law as well. To a large extent, the push to amend the definition became less important with the parallel evolution in the definition of crimes against humanity, principally in its extension to atrocities committed during peacetime. But if the definition of genocide has remained unchanged, in recent years its interpretation has undergone a process of considerable dynamism and radical evolution.

\section{The Evolving Definition of Genocide}

The decisions of the Israeli courts in Eichmann were the only significant judicial interpretations of the definition in the 1948 UNCG for nearly five decades. ${ }^{36}$ On 4 September 1998, the International Criminal Tribunal for Rwanda (ICTR) issued its first major judgment, convicting the bourgmestre of Taba commune of genocide for his role in the 1994 slaughter of Tutsi civilians, including the systematic rape of women and girls. ${ }^{37}$ Many similar judgments were to follow, as one by one the architects of the 1994 genocide were brought to book. The case law of the International Criminal Tribunal for the former Yugoslavia (ICTY) developed more slowly, to a large extent because of a cautious policy on the part of the prosecutor in the indictment of suspects for genocide, in addition to the ubiquitous counts of crimes against humanity and war crimes. The hesitation was not misguided, because, of the handful of ICTY prosecutions that proceeded in which genocide has been alleged, the majority has resulted in acquittals on that count. ${ }^{38}$ But even the acquittals have provided important judicial guidance as to the parameters of the concept. In August 2001, an ICTY Trial 
Chamber registered a first conviction for genocide, condemning a Bosnian Serb general who had participated, albeit in a secondary role, in the massacre of 7,000 Muslim men and boys at Srebrenica in July $1995 .^{39}$ The conviction was subsequently upheld on appeal. ${ }^{40}$ In January 2005, an ICTY Trial Chamber issued the second conviction for genocide in what is arguably the most expansive interpretation yet. ${ }^{41}$ This now relatively rich reservoir of judicial interpretation of the definition of genocide indicates a tendency to enlarge the scope of the crime so as to cover cases of "ethnic cleansing," which some jurists might think is better described under the rubric of "crimes against humanity." This trend toward a large and liberal interpretation may ultimately dilute the terrible stigma that is attached to the crime of genocide. At the same time, it can only complicate the attempts of those who attempt to challenge the use of the term "genocide" to characterize the 1915 massacres of the Armenian minority within Turkey.

\section{State Plan or Policy}

It may seem self-evident that genocide cannot be committed without the existence of a state plan or policy to physically exterminate the targeted group. Certainly, in the cases of all three of the major genocides of the twentieth century-those of the Armenians in the Ottoman Empire, the Jews in occupied Europe, and the Rwandan Tutsi-there is ample evidence of and little argument about the role played by the state. Nevertheless, if this factor is implicit in the definition in the 1948 convention, nothing in the text actually requires it. The ICTY has ruled that proof of a plan or policy is not a legal ingredient of the crime of genocide. The Appeals Chamber has noted, nevertheless, that "in the context of proving specific intent, the existence of a plan or policy may become an important factor in most cases. The evidence may be consistent with the existence of a plan or policy, or may even show such existence, and the existence of a plan or policy may facilitate proof of the crime." ${ }^{2}$ Thus, at least theoretically, an individual acting alone, without any state involvement, may still perpetrate the crime of genocide, provided that he or she intends to destroy a protected group in whole or in part.

\section{Groups Protected}

In Akayesu, the ICTR provided an imaginative and somewhat radical construction of the groups protected by the 1948 definition, which uses the adjectives "national, ethnical, racial or religious." Concerned that none of the four terms of the definition might apply to Rwanda's Tutsi minority, the principal victim of the 1994 atrocities, the tribunal concluded that the UNCG could still extend to certain other groups, although their precise definition was elusive. Pledging fidelity to the convention's drafters, the Akayesu judgment declares,

On reading through the travaux préparatoires of the Genocide Convention (Summary Records of the meetings of the Sixth Committee of the General Assembly, 21 September-10 December 1948, Official Records of the General Assembly), it appears that the crime of genocide was allegedly perceived as targeting only "stable" groups, constituted in a permanent fashion and membership of which is determined by birth, with the exclusion of the more "mobile" groups which one joins through individual voluntary commitment, such as political and economic groups. Therefore, a common criterion in the four types of groups protected by the Genocide Convention is that membership in such groups would seem to be normally not challengeable by its 
members, who belong to it automatically, by birth, in a continuous and often irremediable manner.

The Trial Chamber continues,

Moreover, the Chamber considered whether the groups protected by the Genocide Convention, echoed in Article 2 of the Statute, should be limited to only the four groups expressly mentioned and whether they should not also include any group which is stable and permanent like the said four groups. In other words, the question that arises is whether it would be impossible to punish the physical destruction of a group as such under the Genocide Convention, if the said group, although stable and membership is by birth, does not meet the definition of any one of the four groups expressly protected by the Genocide Convention. In the opinion of the Chamber, it is particularly important to respect the intention of the drafters of the Genocide Convention, which according to the travaux préparatoires, was patently to ensure the protection of any stable and permanent group. ${ }^{43}$

The same ICTR chamber, in a subsequent decision, seems to hedge its remarks somewhat: "It appears from a reading of the travaux préparatoires of the Genocide Convention that certain groups, such as political and economic groups have been excluded from the protected groups, because they are considered to be "mobile groups" which one joins through individual, political commitment. That would seem to suggest a contrario that the Convention was presumably intended to cover relatively stable and permanent groups."44

This interpretation appeared to many at the time to be creative and progressive, but it has not been confirmed by the Appeals Chambers of the tribunals, and it looks increasingly idiosyncratic as time goes by. Nevertheless, other authorities confirm that the list of groups in the UNCG definition should receive a large and liberal interpretation. In January 2005, a non-judicial commission of inquiry established by the United Nations to investigate allegations of genocide in Darfur, in western Sudan, wrote that "the principle of interpretation of international rules whereby one should give such rules their maximum effect (principle of effectiveness, also expressed by the Latin maxim ut res magis valeat quam pereat) suggests that the rules on genocide should be construed in such a manner as to give them their maximum legal effects." 45

\section{"In whole or in part"}

The 1948 definition of genocide speaks of the destruction of a group "in whole or in part." It was a noble attempt by the drafters to reach consensus, but in reality the General Assembly used ambiguous terms and left their clarification to judges in subsequent prosecutions. The 1995 Srebrenica massacre confronted the ICTY with the need to expound upon the meaning of "in whole or in part." According to the ICTY Appeals Chamber, a perpetrator of genocide must intend to destroy a substantial part of the group. The chamber explains,

The determination of when the targeted part is substantial enough to meet this requirement may involve a number of considerations. The numeric size of the targeted part of the group is the necessary and important starting point, though not in all cases the ending point of the inquiry. The number of individuals targeted should be evaluated not only in absolute terms, but also in relation to the overall size of the entire group. In addition to the numeric size of the targeted portion, its prominence within the group can be a useful consideration. If a specific part of the group is emblematic of the overall 
group, or is essential to its survival, that may support a finding that the part qualifies as substantial. $^{46}$

The Appeals Chamber notes that the Bosnian Muslim population in Srebrenica, or the Bosnian Muslims of Eastern Bosnia, a group estimated to comprise about 40,000 people, met this definition. Though numerically not very significant compared to the Bosnian Muslim population as a whole, it occupied a strategic location and was thus key to the survival of the Bosnian Muslim nation as a whole. ${ }^{47}$

\section{Ethnic Cleansing}

The expression "ethnic cleansing" may have been used for the first time immediately after World War II by Poles and Czechs intending to "purify" their countries of Germans and Ukrainians. But if this is the case, the language is the direct descendant of expressions used by the Nazis in their racial "hygiene" programs. The term for the latter was sauberung ("cleaning"), and their goal was to make Germany territory judenrein, that is, clean of Jews. ${ }^{48}$ "Ethnic cleansing" resurfaced in 1981 in Yugoslav media accounts of the establishment of "ethnically clean territories" in Kosovo. ${ }^{49}$ The term entered the international vocabulary in 1992 when it was used to describe policies pursued by the various parties to the Yugoslav conflict in order to create ethnically homogeneous territories. ${ }^{50}$ There have been several attempts at definition. According to the Security Council's Commission of Experts on violations of humanitarian law during the Yugoslav war, "the expression 'ethnic cleansing' is relatively new. Considered in the context of the conflicts in the former Yugoslavia, 'ethnic cleansing' means rendering an area ethnically homogeneous by using force or intimidation to remove persons of given groups from the area." 51 The commission considered techniques of ethnic cleansing to include murder, torture, arbitrary arrest and detention, extrajudicial executions, sexual assault, confinement of civilian populations in ghetto areas, forcible removal, displacement and deportation of civilian populations, deliberate military attacks or threats of attacks on civilians and civilian areas, and wanton destruction of property. ${ }^{52}$

In Krstic', the ICTY Trial Chamber said "there are obvious similarities between a genocidal policy and the policy commonly known as "ethnic cleansing." 53 The Trial Chamber seemed to understand that it was necessary to expand the scope of the term "destroy" in the introductory sentence, or chapeau, of the definition of genocide in order to cover "acts that involved cultural and other non-physical forms of group destruction." ${ }^{54}$ But the judgment also states,

Customary international law limits the definition of genocide to those acts seeking the physical or biological destruction of all or part of the group. An enterprise attacking only the cultural or sociological characteristics of a human group in order to annihilate these elements which give to that group its own identity distinct from the rest of the community would not fall under the definition of genocide. ${ }^{55}$

The Appeals Chamber appeared to endorse this approach. ${ }^{56}$

Nevertheless, in a very recent decision, another trial chamber has ruled that genocide occurs when there is deportation or some other forced displacement of populations, even in the absence of evidence of a plan for physical extermination. Although the Srebrenica massacre involved the summary execution of approximately 7,000 men and boys, the women, children, and elderly were moved from the area in buses, raising questions about whether the Bosnian Serb forces really intended the physical extermination of the entire group or whether they only sought to eliminate persons likely to be enemy combatants. A massacre of prisoners would not, 
in and of itself, amount to genocide. In Blagojevic, the ICTY Trial Chamber concluded that the forced displacement of women, children, and elderly people amounted to genocide:

The Trial Chamber is convinced that the forced displacement of women, children, and elderly people was itself a traumatic experience, which, in the circumstances of this case, reaches the requisite level of causing serious mental harm under Article 4(2)(b) of the Statute. The forced displacement began with the Bosnian Muslim population fleeing from the enclave after a five-day military offensive, while being shot at as they moved from Srebrenica town to Potočari in search of refuge from the fighting. Leaving their homes and possessions, the Bosnian Muslims did so after determining that it was simply impossible to remain safe in Srebrenica town... Having left Srebrenica to escape from the Bosnian Serbs, the Bosnian Muslim population saw that they must move farther than Potočari to be safe. As they boarded the buses, without being asked even for their name, the Bosnian Muslims saw the smoke from their homes being burned and knew that this was not a temporary displacement for their immediate safety. Rather, this displacement was a critical step in achieving the ultimate objective of the attack on the Srebrenica enclave to eliminate the Bosnian Muslim population from the enclave. ${ }^{57}$

The Trial Chamber concludes the discussion of this point by stating that "the perpetrators intended that the forcible transfer, and the way it was carried out, would cause serious mental harm to the victims" and that this fulfills the requirements of Article II of the 1948 definition, set out without significant change in Article 4(2) of the ICTY Statute. ${ }^{58}$

\section{Complicity in Genocide}

The ad hoc tribunals have addressed cases in which senior officials played a secondary role in genocidal acts but there were doubts that these people actually intended to destroy the group. In prosecuting these officials as accomplices rather than principal perpetrators, the ICTY and ICTR Appeals Chambers have held that a conviction may be entered for "aiding and abetting" genocide, ${ }^{59}$ or for "complicity" in genocide,${ }^{60}$ even in the absence of sufficient evidence that the accused person possessed criminal intent to commit genocide. These decisions are not exactly elegant in their legal reasoning, and they strongly hint at compromises among a divided bench. Nevertheless, they now stand as the state of the law, and they provide a further demonstration of the general trend toward enlargement of the definition of genocide that appears in the 1948 UNCG.

The ICTY Appeals Chamber has also found that it is possible to commit genocide as part of a "joint criminal enterprise." The expression "joint criminal enterprise" is used to describe the liability of an individual who participates in a criminal activity with others. As a member of this "joint criminal enterprise," the accused may be convicted of acts that he or she did not actually intend, to the extent that these were reasonably foreseeable consequences of the criminal activity. To some judges, it appeared that a conviction for genocide, which requires proof that the offender committed acts "with intent to destroy" the group, in whole or in part, was theoretically incompatible with the entire concept of the joint criminal enterprise. ${ }^{61}$ However, the prosecutor successfully challenged one of these rulings, and the ICTY Appeals Chamber has established that convictions for genocide are possible under the "joint criminal enterprise" mode of liability. ${ }^{62}$ 


\section{Conclusions}

The definition of genocide adopted by the UN General Assembly in December 1948 represents a dilution of a relatively broad concept proposed by Raphael Lemkin four years earlier. The narrowness of the definition must be appreciated in the context of the time. States were being asked to accept an unprecedented encroachment on their sovereignty, namely, the existence of international obligations with respect to their treatment of civilians of their own nationality within their own borders. The only comparable commitments with respect to human-rights abuses committed in peacetime are the 1973 International Convention on the Suppression and Punishment of the Crime of Apartheid ${ }^{63}$ and the 1984 Convention against Torture and Other Cruel, Inhuman or Degrading Treatment or Punishment. ${ }^{64}$ Both apartheid and torture may constitute crimes against humanity, but a more general undertaking with respect to crimes against humanity in their broad sense had to wait until 1998, with the adoption of the Rome Statute.

Had the Nuremberg trial taken a larger view of crimes against humanity by acknowledging that they could be committed in peacetime as well as in wartime, there might never have been a UNCG. Work on that convention was largely an initiative to correct the lacuna in the Nuremberg definition of crimes against humanity. But the tension that existed between genocide and crimes against humanity in the post-war years no longer exists, given recognition under contemporary international law that crimes against humanity, like genocide, may be committed in time of peace.

Debates about historic cases of genocide need to be reassessed in light of evolving case law. In a series of recent decisions, the international criminal tribunals have broadened the reach of the 1948 definition; it has been held to apply to a somewhat more expansive category of groups than is listed in the text of the definition. No proof of state involvement, or of a policy or plan, is necessary to establish that genocide has been committed; it may even be perpetrated by an individual acting alone. As for those who participate in the crime of genocide, prosecutors need not establish that they actually had a genocidal intent, as long as they were in some way accomplices to the crime. Finally, and perhaps most importantly of all, the concept of genocide has been extended to acts that compromise the survival of a group, such as forced displacements, even when there are doubts about the intent to physically exterminate the group.

None of this can be particularly comforting to those who have tried to deny that the massacres of Armenians within Turkey in 1915 constituted one of the great genocides of the twentieth century.

\section{Acknowledgments}

Earlier versions of this paper have been presented in Yerevan, Armenia, on 20-21 April 2005, at the international conference organized by the National Commission for the Commemoration of the 90th Anniversary of the Armenian Genocide; and in Ankara on 3 January 2006, at the annual meting of the Ankara Bar Association.

\section{Notes}

1. Richard G. Hovannisian, ed., The Armenian Genocide: History, Politics, Ethics (New York: St. Martin's Press, 1991); R. Melson, Revolution and Genocide: On the Origin of the Armenian Genocide and of the Holocaust (Chicago: University of Chicago Press, 1992). 
2. English translation quoted in United Nations War Crimes Commission, History of the United Nations War Crimes Commission and the Development of the Laws of War (London: HMSO, 1948), 35.

3. This initial use of the term "crimes against humanity" was noted in some of the first judgments of the International Criminal Tribunal for the former Yugoslavia (Prosecutor $v$. Tadic, Opinion and Judgment, IT-94-1-T (7 May 1997), para. 618, n. 87) and the International Criminal Tribunal for Rwanda (Prosecutor v. Akayesu, Judgment, ICTR-964-T [2 September 1998], para. 29). The concept of crimes against humanity, however, had been in existence long before 1915. During debates in the National Assembly, French revolutionary Robespierre described King Louis XVI as a "[c]riminal against humanity": Maximilien Robespierre, Euvres, IX (Paris: Presses universitaires de France, 1952), 130. In 1890, an American observer, George Washington Williams, wrote to the US Secretary of State that King Leopold's regime in Congo was responsible for "crimes against humanity": Adam Hochschild, King Leopold's Ghost (Boston: Houghton Mifflin, 1998), 112.

4. “Traité de Sèvres," 1920, art. 226, Recueil général des traités, 1924, UK Treaty Series 11; DeMartens, 99, 3e série, 12, p. 720 [French version].

5. "Treaty of Peace between the Allied and Associated Powers and Germany" ["Treaty of Versailles"], 1919, Treaty Ser. no. 4, arts. 228-30. There were similar penal provisions in the other peace treaties adopted in Paris at the same time: "Treaty of St. Germainen-Laye," 1919, Treaty Ser. no. 11, art. 173; "Treaty of Neuilly-sur-Seine," 1920, Treaty Ser. no. 5, art. 118; "Treaty of Trianon," 1919, 6 L.N.T.S. 187, art. 15.

6. "Traité de Sèvres," art. 226.

7. Kay Holloway, Modern Trends in Treaty Law (London: Stevens \& Sons, 1967), 60-61.

8. "Treaty of Lausanne between Principal Allied and Associated Powers and Turkey," 1923, Treaty Ser. no. 28: 11.

9. Raphael Lemkin, Axis Rule in Occupied Europe: Laws of Occupation, Analysis of Government, Proposals for Redress (Washington, DC: Carnegie Endowment for World Peace, 1944).

10. Lemkin later wrote that "an important factor in the comparatively quick reception of the concept of genocide in international law was the understanding and support of this idea by the press of the United States and other countries." Raphael Lemkin, "Genocide as a Crime in International Law," American Journal of International Law 41 (1947): 145-51, 149 , n. 9.

11. And the French language as well: Raphael Lemkin, "Le crime de génocide," Revue de Droit International, de Sciences Diplomatiques et Politiques 24 (1946): 213-22.

12. The Crime of Genocide, UN General Assembly Resolution 96(I), UN Doc. A/64/Add. 1 (11 December 1946).

13. Convention on the Prevention and Punishment of the Crime of Genocide, 9 December 1948, UN Treaty Ser. no. 78: 277. On the convention generally, see William A. Schabas, Genocide in International Law (Cambridge: Cambridge University Press, 2000); William A. Schabas, Genozid im Völkerrecht (Hamburg: Hamburger Edition, 2003).

14. Agreement for the Prosecution and Punishment of Major War Criminals of the European Axis, and Establishing the Charter of the International Military Tribunal (I.M.T.), 1951, U.N. Treaty Ser. 82: 279, art. VI(c).

15. International Convention Concerning the Laws and Customs of War by Land, 1910, British Treaty Ser. no. 9.

16. Quoted in Vahakn N. Dadrian, "Genocide as a Problem of National and International Law: The World War I Armenian Case and Its Contemporary Legal Ramifications," Yale Journal of International Law 14 (1989): 221-334.

17. Recent advances in human rights and humanitarian law have now eliminated the nexus between crimes against humanity and international armed conflict: Prosecutor $v$. Tadic, IT-94-1-AR72, Decision on the Defense Motion for Interlocutory Appeal on Jurisdiction (2 October 1995), paras. 78, 140, 141; Prosecutor v. Kordić \& Cerkez, 
IT-95-14/2-T (26 February 2001), para. 33; Rome Statute of the International Criminal Court, UN Doc. A/CONF.183/9, (1998) 37 I.L.M. 999, art. 7.

18. International Conference on Military Tribunals (London, 1945), minutes of conference session of 23 July 1945, 333.

19. France et al. v. Goering et al., 22 IMT 203 (1946).

20. Lemkin, Axis Rule in Occupied Europe, 79.

21. UN Doc. A/BUR.50. For a summary of the history of the resolution, see UN Doc. E/621.

22. Ibid. The General Assembly decided to include the point in its agenda (UN Doc. A/181), and the matter was referred to the Sixth Committee (UN Doc. A/C.6/64).

23. UN GA, The Crime of Genocide.

24. UN Doc. A/C.6/232/Rev.1. See also UN Doc. A/C.6/233; UN Doc. A/C.6/223.

25. See UN Doc. A/C.6/SR.82.

26. Beth Van Schaack, “The Crime of Political Genocide: Repairing the Genocide Convention's Blind Spot," Yale Law Journal 106 (1997): 2259-91. See also Lawrence J. LeBlanc, "The United Nations Genocide Convention and Political Groups: Should the United States Propose an Amendment?" Yale Journal of International Law 13 (1988): 268-95; Stefan Glaser, Droit international pénal conventionnel (Brussels: Bruylant, 1970), 112; Stanislav Plawski, Étude des principes fondamentaux du droit international pénal (Paris: Librairie générale de droit et de jurisprudence, 1972), 114; "Study of the Question of the Prevention and Punishment of the Crime of Genocide: Study prepared by Mr. Nicodème Ruhashyankiko, Special Rapporteur," UN Doc. E/CN.4/Sub.2/416, para. 87.

27. Glaser, Droit international, para. 83.

28. Israel W. Charny, "Toward a Generic Definition of Genocide," in Genocide Conceptual and Historical Dimensions, ed. George J. Andreopoulous, 64-94 (Philadelphia: University of Pennsylvania Press, 1994), 75: "Genocide in the generic sense is the mass killing of substantial numbers of human beings, when not in the course of military action against the military forces of an avowed enemy, under conditions of the essential defenselessness and helplessness of the victims."

29. Vahakn Dadrian, "A Typology of Genocide," International Review of Modern Sociology 5 (1975): 201-12, 201: "Genocide is the successful attempt by a dominant group, vested with formal authority and/or with preponderant access to the overall resources of power, to reduce by coercion or lethal violence the number of a minority group whose ultimate extermination is held desirable and useful and whose respective vulnerability is a major factor contributing to the decision for genocide."

30. Helen Fein, "Genocide, Terror, Life Integrity, and War Crimes," in Genocide, Conceptual and Historical Dimensions, ed. George J. Andreopoulous, 95-107 (Philadelphia: University of Pennsylvania Press, 1994), 97: "Genocide is sustained purposeful action by a perpetrator to physically destroy a collectivity directly or through interdiction of the biological and social reproduction of group members."

31. Frank Chalk and Kurt Jonassohn, "The Conceptual Framework," in The History and Sociology of Genocide, ed. Frank Chalk and Kurt Jonassohn, 3-43 (New Haven, CT: Yale University Press, 1990), 23: "Genocide is a form of one-sided mass killing in which a state or other authority intends to destroy a group, as that group and members in it are defined by the perpetrator." See also Frank Chalk, "Redefining Genocide," Genocide, Conceptual and Historical Dimensions, ed. George J. Andreopoulous, 47-63 (Philadelphia: University of Pennsylvania Press, 1994), 52; Frank Chalk, "Definitions of Genocide and Their Implications for Prediction and Prevention," Holocaust and Genocide Studies 4 (1989): 149-60. Chalk and Jonassohn's proposed definition is endorsed by Irving Louis Horowitz, in Taking Lives: Genocide and State Power, 4th ed. (New Brunswick, NJ: Transaction Publishers, 1997), 12-13.

32. Pieter Nicolaas Drost, The Crime of State, vol. 2, Genocide (Leiden: A.W. Sijthoff, 1959), 122-23. 
33. Statute of the International Criminal Tribunal for the Former Yugoslavia, UN Doc. S/RES/ 827, annex, art. 4; Statute of the International Criminal Tribunal for Rwanda, UN Doc. S/RES/955, annex, art. 2.

34. Report of the International Law Commission on the Work of Its Forty-Eighth Session, 6 May-26 July 1996, UN Doc. A/51/10, 86-87.

35. Rome Statute; see William A. Schabas, "Article 6," in Commentary on the Rome Statute of the International Criminal Court, Observers' Notes, Article by Article, ed. Otto Triffterer, 107-16 (Baden-Baden: Nomos Verlagsgesellschaft, 1999).

36. Israel (A.G.) v. Eichmann (1968), 36 ILR 18 (District Court, Jerusalem); Israel (A.G.) v. Eichmann (1968), 36 ILR 277 (Israel Supreme Court).

37. Akayesu.

38. Prosecutor v. Jelisić, Judgment, IT-95-10-T (14 December 1999); Prosecutor v. Sikirica et al., Judgment on Defense Motions to Acquit, IT-95-8-I (3 September 2001); Prosecutor $v$. Stakic', Judgment, IT-97-24-T (31 July 2003); Prosecutor v. Brđanin, Judgment, IT-99-36-T (1 September 2004).

39. Prosecutor v. Krstić, Judgment, IT-98-33-T (2 August 2001) [Krstić Trial Judgment].

40. Prosecutor v. Krstić, Judgment, IT-98-33-A (19 April 2004) [Krstić Appeals Judgment].

41. Prosecutor v. Blagojević et al., Judgment, IT-02-60-T (17 January 2005).

42. Prosecutor v. Jelisić, Judgment, IT-95-10-A (5 July 2001), para. 48.

43. Akayesu, para. 515.

44. Prosecutor $v$. Rutaganda, Judgment, ICTR-96-3-T (6 December 1999) [reference omitted]. See also Prosecutor v. Musema, Judgment, ICTR-96-13-T (27 January 2000), para. 162.

45. Report of the International Commission of Inquiry on Darfur to the United Nations Secretary-General (25 January 2005), http://www.un.org/News/dh/sudan/ com_inq_darfur.pdf (accessed 14 July 2006), para. 494.

46. Krstić Appeals Judgment, para. 12.

47. Ibid., paras. 15-16.

48. Mark Kramer, "Introduction," in Redrawing Nations: Ethnic Cleansing in East Central Europe, ed. Mark Kramer, 1-41 (Boulder, CO: Rowman \& Littlefield, 2001), 1.

49. Drazen Petrovic, "Ethnic Cleansing: An Attempt at Methodology," European Journal of International Law 5 (1994): 343-59.

50. See Norman Cigar, Genocide in Bosnia: The Policy of Ethnic Cleansing (College Station: Texas A\&M University Press, 1995); Nathan Lerner, "Ethnic Cleansing," Israel Yearbook of Human Rights 24 (1994): 103-17; John Webb, "Genocide Treaty_Ethnic CleansingSubstantive and Procedural Hurdles in the Application of the Genocide Convention to Alleged Crimes in the Former Yugoslavia," Georgia Journal of International and Comparative Law 23 (1993): 377-408; Damir Mirkovic, "Ethnic Cleansing and Genocide: Reflections on Ethnic Cleansing in the Former Yugoslavia," Annals of the American Academy of Political and Social Science 548 (1996): 191-99; Andrew Bell-Fialkoff, "A Brief History of Ethnic Cleansing," Foreign Affairs 72 (1993): 110-21.

51. Interim Report of the Commission of Experts Established Pursuant to Security Council Resolution 780 (1992), UN Doc. S/25274 (1993), para. 55.

52. Ibid., para. 56.

53. Krstić Trial Judgment, para. 562.

54. Ibid., para. 577.

55. Ibid., para. 580.

56. Krstić Appeals Judgment, para. 25.

57. Blagojević, para. 650.

58. Ibid., para. 654 .

59. Krstić Appeals Judgment, paras. 135-44.

60. Prosecutor v. Ntakirutimana et al., Judgment, ICTR-96-10-A, ICTR-96-17-A (13 December 2004), para. 500. 
61. Prosecutor v. Stakic, Decision on Rule 98 bis Motion for Judgment of Acquittal, IT-97-24-T (31 October 2002), para. 93; Prosecutor v. Brdanin, Decision on Motion for Acquittal Pursuant to Rule 98 bis, IT-99-36-T (8 November 2003), paras. 30, 55-57.

62. Prosecutor v. Brđanin, Decision on Interlocutory Appeal, IT-99-36-A (19 March 2004).

63. International Convention on the Suppression and Punishment of the Crime of Apartheid, 30 November 1973, 1015 U.N.T.S., 243, 244.

64. Convention against Torture and Other Cruel, Inhuman or Degrading Treatment or Punishment, 10 December 1984, 1465 U.N.T.S., 85. 